\title{
Unexpected Small-Bowel Finding in Overt-Obscure Gastrointestinal Bleeding in a Patient with Neurofibromatosis Type 1 and Crohn's Disease
}

\author{
Catarina Gomes $^{a} \quad$ Ana Ponte $^{\mathrm{a}}$ Rolando Pinho ${ }^{\mathrm{a}} \quad$ Adélia Rodrigues $^{\mathrm{a}}$ João Carvalho ${ }^{\mathrm{a}}$ \\ ${ }^{a}$ Gastrenterology Department, Centro Hospitalar Vila Nova de Gaia/Espinho, Vila Nova de Gaia, Portugal
}

Keywords

Gastrointestinal stromal tumors · Crohn's disease .

Neurofibromatosis type $1 \cdot$ Gastrointestinal bleeding

\section{Abstract}

Gastrointestinal stromal tumors (GIST) are the most frequent mesenchymal neoplasms affecting the gastrointestinal tract, and the small bowel is the second most frequent location. Approximately $5 \%$ of patients with GIST are not sporadic and have a familial autosomal dominant syndrome, such as neurofibromatosis type 1 (NF1). Gastrointestinal bleeding is a common presentation of GIST, and lesions such as submucosal tumors may be detected more readily by capsule endoscopy due to luminal impingement and overlying ulceration. Our report emphasizes the importance of small-bowel investigation in patients with Crohn's disease and NF1 presenting with recent overt bleeding.

\footnotetext{
(C) 2021 Sociedade Portuguesa de Gastrenterologia Published by S. Karger AG, Basel
}

\section{Achado do intestino delgado inesperado na hemorragia gastrointestinal obscura manifesta em doente com neurofibromatose tipo 1 e Doença de Crohn}

\section{Palavras Chave}

Tumores do estroma gastrointestinal · Doença de Crohn . Neurofibromatose tipo $1 \cdot$ Hemorragia gastrointestinal

\section{Resumo}

Os tumores do estroma gastrointestinal (GIST) são as neoplasias mesenquimatosas que mais frequentemente afetam o trato gastrointestinal, e o intestino delgado é a segunda localização mais comum. Aproximadamente 5\% dos GIST não são esporádicos e estão associados a uma síndrome autossómica dominante familiar, como a neurofibromatose tipo 1 (NF1). A hemorragia gastrointestinal é uma apresentação habitual dos GIST, e as lesões subepiteliais podem ser detectadas através da cápsula endoscópica devido à procidência luminal com ulceração subjacente em alguns casos. O nosso caso clínico enfatiza a importância da investigação do intestino delgado numa doente com doença de Crohn e NF1 que apresentou uma hemorragia gastrointestinal.

(C) 2021 Sociedade Portuguesa de Gastrenterologia Publicado por S. Karger AG, Basel

\section{Introduction}

The most frequent mesenchymal neoplasms affecting the gastrointestinal (GI) tract are GI stromal tumors (GIST). GIST are most often located in the stomach (60-70\%), followed by the small bowel (20-35\%), the colon and rectum $(5 \%)$, and the esophagus $(<5 \%)[1,2]$. Although the majority of GIST are sporadic, approximately $5 \%$ of patients have 1 of several familial autosomal dominant syndromes, such as primary familial GIST syndrome, neurofibromatosis type 1 (NF1), or Carney-Stratakis syndrome [3].

karger@karger.com www.karger.com/pjg

Karger

GOPEN ACCESS
(C) 2021 Sociedade Portuguesa de Gastrenterologia Published by S. Karger AG, Basel

This is an Open Access article licensed under the Creative Commons Attribution-NonCommercial-4.0 International License (CC BY-NC) (http://www.karger.com/Services/OpenAccessLicense), applicable to the online version of the article only. Usage and distribution for commercial purposes requires written permission. 
Fig. 1. Small bowel findings of a $4-\mathrm{cm}$ ulcerated subepithelial lesion with bleeding stigmata suggestive of a GIST. a, b Capsule endoscopy images. c, d Single-balloon enteroscopy images.
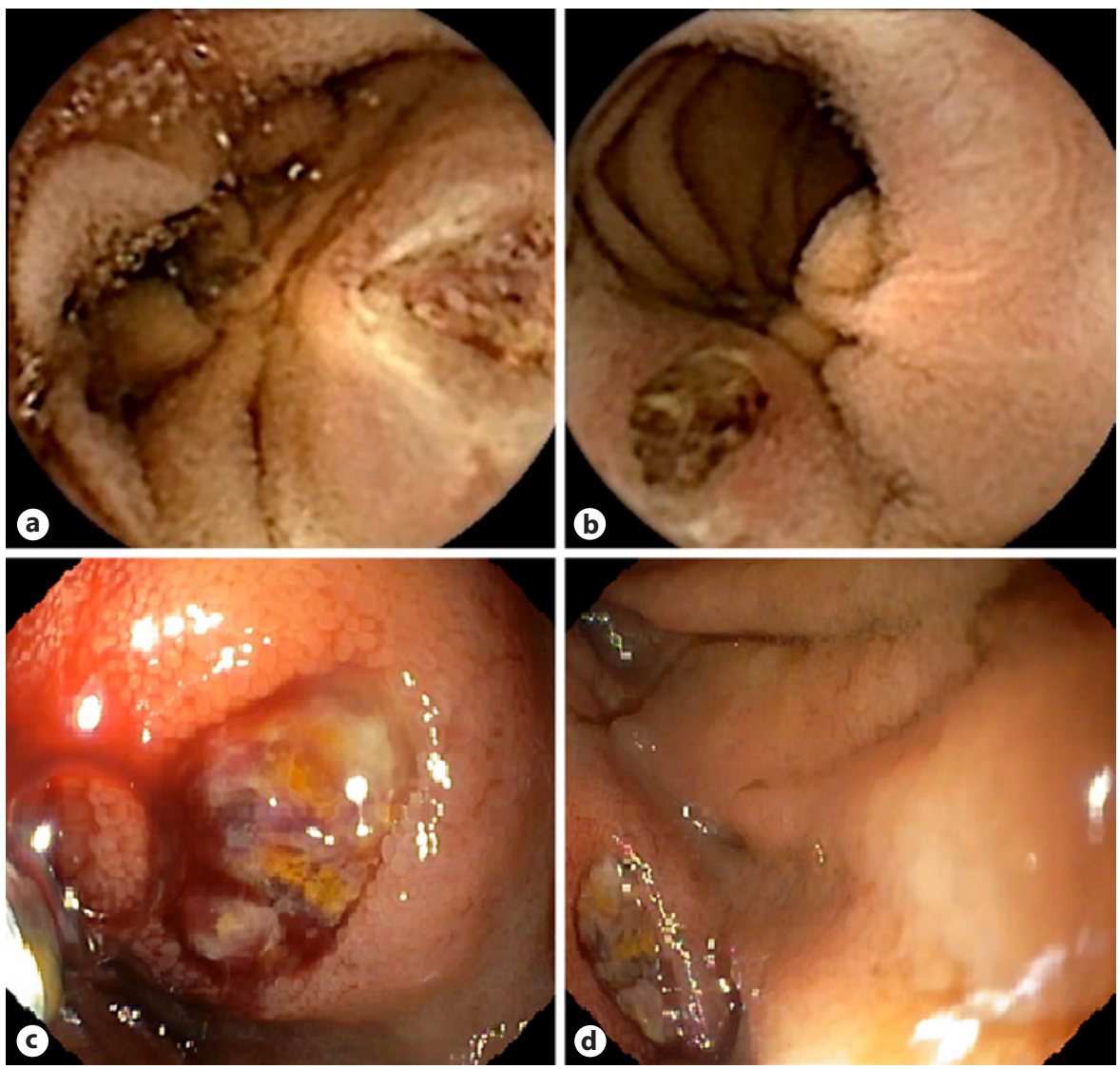

These tumors are identified mainly by expression of the KIT protein (95\%), and they frequently harbor activating mutations in the KIT or platelet-derived growth factor- $\alpha$ PDGFRA receptor genes [1]. The most prominent diagnostic marker of GIST is overexpression of the receptor tyrosine kinase KIT (CD117) (90\%), which is easily recognized by positive immunohistochemical staining [1]. Almost 75\% of GIST are composed of spindle cells, whereas the remaining GIST consist of epithelioid cells [1].

GIST are more frequently associated with GI bleeding and acute abdomen due to tumor ulceration and their large growth, respectively. Nevertheless, patients could be asymptomatic and GIST can be incidentally detected during endoscopic study or cross-sectional imaging, or patients could only report nonspecific symptoms (e.g., early satiety and bloating) [3].

Multiple procedures are commonly used to investigate small bowel tumors, although lesions presented as submucosal tumors may be detected more readily by capsule endoscopy $[2,4]$.

Unexpected Finding in NF1 and CD

\section{Case Report}

A 58-year-old woman presented to the emergency department with a 5-day history of melena. Her medical history included an inflammatory ileocolonic Crohn disease (CD) (Montreal classification: A2L3B1) and NF1, without current medication. Ileocolonoscopy and magnetic resonance enterography performed 3 and 4 years ago, respectively, were unremarkable, and she was in clinical CD remission. An abdominal examination did not reveal any pain or abnormal mass. A laboratory study revealed normocytic normochromic anemia (hemoglobin, $8 \mathrm{~g} / \mathrm{dL}$; mean corpuscular volume, $82.6 \mathrm{fL}$; and mean corpuscular hemoglobin concentration, $32.5 \mathrm{~g} / \mathrm{dL}$ ). She underwent an esophagogastroduodenoscopy, the results of which were normal. Taking into account her CD history, a panenteric capsule endoscopy was performed. Capsule endoscopy did not detect the presence of active disease, although it demonstrated an ulcerated subepithelial lesion with bleeding stigmata presumably in the proximal jejunum (Fig. $1 \mathrm{a}-\mathrm{b}$ ). Anterograde single-balloon enteroscopy confirmed a 4 -cm ulcerated protruding lesion, suggestive of a GIST, and a tattoo was placed proximally (Fig. $1 \mathrm{c}-\mathrm{d}$ ). Computed tomography showed a heterogeneous enhanced small bowel exophytic lesion of around $9 \mathrm{~cm}$, suggestive of a GIST, with intimate contact with the bladder, the appendix, and the sigmoid colon but without evident invasion of those structures (Fig. 2). The patient underwent laparoscopy and small-bowel resection with end-to-end anastomosis. During surgery, tumor

GE Port J Gastroenterol 2022;29:348-351 
rupture was verified. Pathology confirmed a GIST of the epithelioid cell subtype, with a mitotic rate of $2 / 5 \mathrm{~mm}^{2}$, without KIT or PDGFRA mutations. Margins were free of tumor, and the TNM staging was pT3. By immunohistochemistry, cells were positive for CD34, CD117, and DOG-1. AT the time of writing, the patient was on imatinib and fluorodeoxyglucose positron emission tomography performed 3 months after surgery revealed no evidence of relapse.

\section{Discussion}

GIST arising in the GI tract are typically found as a subepithelial lesion, and as they grow this could lead to epithelial ulceration which could ultimately manifest as GI bleeding $[2,5,6]$. Individuals, like our patient, with NF1 have a significantly increased risk of GIST (5-25\%) especially in the small bowel (>70\%), and, unlike the sporadic type, these patients usually do not carry somatic mutations in the KIT or PDGFRA genes [7]. Curiously, overexpression of KIT may be present even in the absence of KIT mutations, especially in the setting of NF1, as noticed in this patient's tumor with CD117 staining [7].

GIST have potential for malignant behavior, and some prognostic factors were already evaluated, such as tumor size $(>5 \mathrm{~cm})$, mitotic activity ( $>5$ mitoses per $50 \mathrm{HPF}$ ), tumor location (small bowel or rectal), depth invasion, grade differentiation, tumor rupture, and presence of KIT mutation. Furthermore, some other tumor characteristics on CT or endoscopic ultrasound, such as lobulated morphology, heterogeneous enhancement, mesenteric fat infiltration, ulceration, regional lymphadenopathy, or an exophytic growth pattern, are considered to be more susceptible to metastasis [8]. In patients with a risk of relapse, adjuvant treatment with imatinib at $400 \mathrm{mg}$ for 3 years is advisable [3]. Even though our patient presented some high risk features, such as the presence of a smallbowel large tumor with heterogeneous enhancement, exophytic growth, and tumor rupture, since NF1-GIST oncogenesis is attributed to activation of the RAS/RAF/ MAP kinase signaling pathway, these tumors rarely respond to imatinib and no standard drug therapy for relapsed tumors has been established $[7,9]$. In the present case, the authors reluctantly administered imatinib as first-line therapy since another tyrosine kinase inhibitor was not available.

Our report emphasizes the importance of small-bowel investigation in this patient with 2 simultaneous important chronic entities, i.e., CD and NF1, who presented an overt bleeding episode. Although the patient's clinical


Fig. 2. Computed tomography showing a small-bowel exophytic GIST of around $9 \mathrm{~cm}$ with intimate contact with the bladder, the appendix, and the sigmoid colon but without evident invasion of those structures.

presentation could have misled us to suspect of a CD flare, the association between NF1 and GIST motivated a timely capsule endoscopic evaluation, which prevented a delay in the subsequent management, i.e., a surgical approach. As small bowel GIST are considerably incident in patients with NF1, it is questionable whether these patients should be screened with capsule endoscopy. As has been previously recognized [10], there is not yet sufficient evidence to support this type of screening program in this group of patients.

\section{Statement of Ethics}

Written informed consent was obtained from the patient for publication of this case report and any accompanying images. 


\section{Conflict of Interest Statement}

The authors have no conflict of interests to declare.

\section{Funding Sources}

No funding was received for this study.

\section{References}

1 Miettinen M, Lasota J: Gastrointestinal stromal tumors: definition, clinical, histological, immunohistochemical, and molecular genetic features and differential diagnosis. Virchows Arch. 2001;438:1-12.

2 Nakatani M, Fujiwara Y, Nagami Y, Sugimori S, Kameda N, Machida H, et al. The usefulness of double-balloon enteroscopy in gastrointestinal stromal tumors of the small bowel with obscure gastrointestinal bleeding. Intern Med. 2012;51(19):2675-82.

3 Miettinen M, Makhlouf H, Sobin LH, Lasota J. Gastrointestinal stromal tumors of the jejunum and ileum: a clinicopathologic, immunohistochemical, and molecular genetic study of 906 cases before imatinib with long-term follow-up. Am J Surg Pathol. 2006 Apr;30(4):477-89.

\section{Author Contributions}

Case conception: Ana Catarina Gomes and Ana Ponte. Data collection: Adélia Rodrigues. Draft preparation: Ana Catarina Gomes, Ana Ponte, and Rolando Pinho. Revision of this work: João Carvalho. All of the authors reviewed the results and approved the final version of this work.
4 Kauser R, Kazemi A, Farah K, Morrissey S: Easy to swallow: detection of an extramural jejunal GIST by video capsule endoscopy. BMJ Case Rep. 2015. doi: 10.1136/bcr-2015211192.

5 Santos SC, Leite C, Pinho H, Casimiro C. Jejunoileal GIST: A rare case of transient intussusception and gastrointestinal bleeding. Case Rep Surg. 2019 Apr;2019:1492965.

6 Giestas S, Almeida N, Martins R, Canhoto A, Oliveira P, Figueiredo P, et al. Small Bowel GIST: Clinical Presentation as Intussusception and Obscure Bleeding. GE Port J Gastroenterol. 2016 Feb;23(5):279-81.

7 Miettinen M, Fetsch JF, Sobin LH, Lasota J. Gastrointestinal stromal tumors in patients with neurofibromatosis 1: a clinicopathologic and molecular genetic study of 45 cases. Am J Surg Pathol. 2006 Jan;30(1):90-6.
8 Burkill GJ, Badran M, Al-Muderis O, Meirion Thomas J, Judson IR, Fisher C, et al. Malignant gastrointestinal stromal tumor: distribution, imaging features, and pattern of metastatic spread. Radiology.2003 Feb;226(2):52732.

9 Mussi C, Schildhaus HU, Gronchi A, Wardelmann E, Hohenberger P. Therapeutic consequences from molecular biology for gastrointestinal stromal tumor patients affected by neurofibromatosis type 1 . Clin Cancer Res. 2008 Jul;14(14):4550-5.

10 Takakura K, Kajihara M, Sasaki S, Nagano T, Ohta A, Ikegami M, et al. Use of balloon enteroscopy in preoperative diagnosis of neurofibromatosis-associated gastrointestinal stromal tumours of the small bowel: a case report. Case Rep Gastroenterol. 2011 May;5(2):30814. 